\title{
MISIUNEA EUHARISTICĂ A BISERICII VERSUS HEDONISMUL ECOLOGIC
}

Eugen Menut Pintea

\begin{abstract}
A society which lives as if God were dead changes the world into an inferno, haunted by all sorts of totalitarian passions, illusions and idolatries. Without the system of evangelical values which distinguish between good and evil, between moral and immoral, one slips into what Saint Paul calls "the mystery of iniquity". Therefore, it is no wonder that we have turned from guardian angels of creation into destructive demons, in such a way that a warning signal surrounds the planet.

The theological perspective of the world as a gift entrusted to man, as well as man's sacrifice and endeavour of acknowledging the world as Eucharist, partaking of the "reasons of divine love", can put forth a clear understanding of what man's relation to nature means.
\end{abstract}

Keywords: ecological postmodernity, ecological hedonism, Eucharistic vocation, divine reasons, eco-ascetism.

Considerându-se singurul ,actor” în lume, omul postmodern a încercat să reconstruiască lumea, refuzând să o accepte aşa cum a primit-o de la Creator. Aşa se face că tot ceea ce făptura a țesut cu răbdare - proniată de Domnul său - în miliarde de ani, omul aproape a reuşit să distrugă în numai 200 ani de civilizaţie industrială. Inginereşte, omul a intervenit în toate: în trupul său, în ființa viețuitoarelor necuvântătoare, în ecosistemul planetar. Astfel, în ultimii 30 de ani jumătate din păduri au dispărut, 40\% din solurile agricole au fost degradate, jumătate din mlaştini au fost inundate sau secate, etc. Iar consecințele sunt bine cunoscute: pânza freatică a fost redusă, inundațiile sunt tot mai frecvente, apa evaporată în atmosferă 
este redusă, generând modificări ale climatului, nivelul dioxidului de carbon din atmosferă a crescut, iar speciile dispar în prezent cu o viteză mai mare decât au dispărut în ultimii 65 milioane de ani ${ }^{1}$. Pornind de la aceste situații, nu mai este nici o îndoială că protecția naturii ocupă o poziție tot mai privilegiată în preocupările şi idealurile conştiinței contemporane, interpelând astfel Biserica la o abordare a eticii mediului înconjurător ${ }^{2}$.

\section{Ecologia în postmodernitate: de la nihilismul postmodern la hedonismul ecologic}

Deşi pentru un creştin ce trăieşte în duhul lui Hristos, responsabilitatea pentru natură (care face parte din creația lui Dumnezeu) a existat dintotdeauna, societatea postmodernă şi postmoralistă ${ }^{3}$, constatând agravarea catastrofelor ecologice, revendică o nouă ,etică a mediului” întrucât ,etica clasică”, preocupată de aproapele nostru, nu mai pare suficientă. Aşadar, civilizația tehnicistă în care trăim propune o ,etică a viitorului” care proclamă o responsabilitate pe termen lung, obligația necondiționată de a ocroti existența omenirii pe pământ. „Cetățenia postmodernă este mai puțin politică şi mai mult ecologică, nu mai credem într-o

\footnotetext{
$1 * * *$, Justice, peace and Integrity of Creation, Documents from an Ecumenical Process of Commitment, Edited by D. Preman Niles, Geneva, WCC Publications, 1994, pp. 208-210.

2 Patriarhia Ecumenică a stabilit ca data de 1 septembrie să fie numită ,ziua creației”, ca omul să conștientizeze, să folosească și să se bucure rațional de bunurile oferite şi nu să distrugă sau să epuizeze resursele natural, prin lăcomie.

3 Societatea postmoralistă este cea care a renunțat la noțiunea de sacrificiu. Principiul responsabilității apare ca sufletul însuşi al culturii postmoraliste; însă responsabilitatea nu este una însuflețită de imperativul desprinderii de scopurile proprii, ci de un efort de conciliere a valorilor şi intereselor, a principiului drepturilor individului şi constrângerilor vieţii sociale, economice şi ştiinţifice. Cf. Gilles Lipovetsky, Amurgul datoriei, Etica dureroasă a noilor timpuri democratice, Trad. Victor-Dinu Vlădulescu, Bucureşti, Edit. Babel, 1996, pp. 233-234; Vezi şi Robin Gill, Chiristian Ethics in Secular Worlds, Edinburgh, T\&T Clark, 1987.
} 
educaţie morală şi civică orientată către formarea sentimentelor patriotice şi altruiste, nu mai aspirăm decât la o cetățenie verde" ". Or, dreptul la „cetățenia verde” primeşte în postmodernism o nouă dimensiune. Se constată o relaţie indisolubilă între ecologia şi societatea postmodernă care, din dorința de a aduce soluții la provocările şi criza apărută în natură, a degenerat într-o industrie profitabilă.

Renunţând la orice element religios şi transcendental, posmodernismul se caracterizează prin ,,acceptarea necondiționată a efemerităţii, fragmentării, discontinuităţii şi haosului" "s, trasături specifice în toate planurile existenței umane. Lumea postmodernă care e stăpânită de relația dintre „putere şi cunoaştere" (Foucault), va fi supusă, potrivit lui Ignacio Ramonet, unei ,geopolitici a haosului" concretizată prin evoluții pline de incertitudine şi angoasă: explozia demografică, mondializarea economiei, destructurarea politicii, frgmentarea culturilor, la care se adaugă, într-un mod special, amenințările ecologice, epuizarea resurselor naturale ale planetei, efectul de seră, deşertificarea etc. Aceeaşi ,îmbrăţişare a haosului", care sfidează toate paradigmele sociale sănătoase (1-am putea numi haos irațional, căci e creat de omul irațional) se evidenţiază şi în creşterea scandaloasă a marginalizărilor şi excluderilor, a inegalităţilor şi discriminărilor economice şi sociale într-o lume fracturată, în care o cincime din umanitate deține $80 \%$ din resursele planetei, iar o altă cincime, cea mai săracă, doar $0,5 \%$ în care doar 500 de milioane de oameni trăiesc confortabil, iar 4,5

${ }^{4}$ Ibidem, p. 242.

${ }^{5}$ David Harvey, Condiția postmodernității, O cercetare asupra originilor schimbării culturale, trad Cristina Gyurcsik şi Irina Matei, Timişoara, Edit. Amarcord, 2002, p. 52.

${ }^{6}$ Ibidem, p. 53.

7 David Lyon, Postmodernitatea, trad. Luana Schidu, Bucureşti, Edit. DU Style, 1998, p. 118. 
miliarde de semeni se zbat în sărăcie şi nevoi ${ }^{8}$. Prin lumea fragmentată şi atomizată se împlineşte dictonul: divide et impera!, „haosul” devenind unicul mod de exercitare a puterii, iar puterea înseamnă nihilism ${ }^{9}$, adică puterea aparține voinței individului de a răsturna valorile.

Experiența puterii nu este în societatea postmodernă strict legată de posesia unui obiect material, ci puterea este de natură ideologică. „Puterea în libertate, puterea neîndiguită de rituri sau justificări ideologice ale societăţii este agresivitatea în stare pură" ${ }^{\prime \prime}$. Pentru I. P. Culianu, omul postmodern este redus la fluxul temporal al producției şi consumului în care ființa este confiscată nihilist de posesiune, ca esență a puterii. De la un ,nihilism metafizic”, de la atitudinea de negare a celor văzute în favoarea celor nevăzute în modernitate, s-a ajuns în postmodernitate la un ,nihilism antimetafizic", ca atitudine de negare a tot ceea ce nu intră în carapacele minţii umane şi ale instrumentalismului ştiinţific ${ }^{11}$.

Dacă relativismul cunoaşterii şi nihilismul sunt trăsături cheie ale postmodernitătiii, atunci este evident că „embrionul nihilismului a început să se formeze în pântecele modernității", ${ }^{2}$. Friedrich Nietzsche, unul dintre precursorii postmodernismului, care şi-a asigurat notorietatea prin proclamarea „morții lui Dumnezeu”, a arătat că nihilismul se naşte atunci când atitudinea mereu neîncrezătoare a rațiunii moderne se întoarce împotriva rațiunii însăşi $1^{13}$. Sintagma propusă de Nietzsche, „moartea lui Dumnezeu”, înseamnă că „nu mai putem fi siguri de nimic. Moralitatea e o minciună, adevărul e ficțiune. Opțiunea dionisiacă de a accepta

8 Ioan I. Ică jr, Globalizarea-mutații şi provocări, în „Gândirea socială a Bisericii, Fundamente-documente-analize-perspective", Volum realizat şi prezentat de Ioan I. Ică jr şi Germano Marani, Sibiu, Edit. Deisis, 2002, p. 482.

${ }^{9}$ Ioan Petru Culianu, Religie şi Putere, Edit. Nemira, Bucureşti, 1996, p. 227.

${ }^{10}$ Ibidem, p. 226.

${ }^{11}$ Idem, Arborele gnozei. Mitologia gnostică de la creştinismul timpuriu la nihilismul modern, Bucureşti, Edit. Nemira, 1998, p. 356.

${ }^{12}$ David Lyon, op. cit., p. 39.

${ }^{13}$ Ibidem, p. 41. 
nihilismul, de a trăi fără iluzii şi pretenții, dar cu entuziasm, cu bucurie, e tot ce mai supraviețuieşte. Prin urmare, nu mai rămâne nimic din diferența dintre adevăr şi greșeală; e pură amăgire"14. Şi dacă principiul fondator al modernității este „Dumnezeu a murit”, strigătul de mobilizare al postmodernității este „Dumnezeu a murit şi trebuie să fie tinut în continuare mort"

Postmodernitatea este nihilistă prin excelență, adică e o pură rătăcire care ne sugerează nu doar că şi temeiul ultim (adică Dumnezeu) trebuie să fie un simulacru, ci şi că orice gând bazat pe ideea de transcendență este în sine fie fals, fie ilegal ${ }^{16}$. Pentru H. Patapievici, ,postmodernitatea este o noutate de recesie: este mai nouă pentru că este, într-un sens, la fel de recentă; şi este o agresivitate de un alt tip, e adevărat, însă este una doar de stil, nu de esență. Ceea ce cu adevărat s-a epuizat în modernitate, pentru a deveni postmodernitate, nu este modernitatea însăşi: ci aspectul ei exterior" $" 17$. Înțelegem că postmodernitatea este modul în care noi oamenii trăim o viață care nu mai este limitată de absolut nimic, ,un eclectism de piață de tip laissez-faire" 18 , în care viața nu mai este „de esență”, ci doar „,de stil”. Piaţa şi mediile confiscă total munca şi timpul oamenilor care de dragul lui a consuma, a vedea, a se distra, uită să conjuge verbele esențiale: a fi, a locui, a gândi, a se îngriji, a se ruga, subordonând prin tehno-ştiință şi spectacolul mediatic politica, cultura, arta etc., triadei perverse Producție, Profit, Consum/Spectacol/Comunicare. Mutaţia este mult mai profundă şi se petrece în plan ontologic, după G Vattimo, prin reducerea nihilistă a ființelor la obiecte şi marfă şi a ființei însăşi la bunăstare sau la simpla valoare de schimb ${ }^{19}$ sau, cum ar spune H Patapievici, mutația

\footnotetext{
${ }^{14}$ Ibidem, p. 42.

${ }^{15}$ H. R. Patapievici, Omul recent, $O$ critică a modernităţiidin perspectiva intrebării „Ce se pierde atunci când ceva se câştigă?”, Bucureşti, Edit. Humanitas, 2005, p. 417.

${ }^{16}$ H. R. Patapievici, op. cit., p. 417.

${ }^{17}$ Ibidem, p. 116.

${ }^{18}$ David Harvey, op. cit., p. 50.

${ }^{19}$ Ioan I. Ică jr, op. cit., p. 487.
} 
reprezintă „proeminența epistemologiei asupra ontologiei” ${ }^{20}$ prin care tot ceea ce există este o „,construcție de cunoaştere”, lumea devenind un joc al aparențelor, „un stil”, care a dat naştere unei psihologii a traumei ${ }^{21}$.

Din moment ce s-a realizat trecerea de la esență la aparență, de la ontologie la epistemologie, natura înconjurătoare a fost dezbrăcată de tot ceea ce înseamnă prezență sacră şi a fost transformată într-un obiect al cunoaşterii omului. Lumea pe care noi o numim „profană” este, de fapt, o lume profanată de către omul care a căzut din starea de raţionalitate într-o stare de amnezie şi atrofiere a conştiinței sau, mai concret, într-o stare de „nesimțire duhovnicească”, după limbajul filocalic.

Nihilismul existențial postmodern care separă pe om de Dumnezeu şi de natură a dus, fără îndoială, la criza morală şi criza ecologică a societății noastre. De fapt, cele două crize nici nu pot fi despărțite. „Moralitatea ambivalentă” postmodernă care a determinat ca „fenomenele morale să fie în mod natural «neraţionale»" 22 culminează prin lipsa oricărui „,cod etic” sau duce la o „moralitate neaporetică, neambivalentă, o etică universală şi «obiectiv fondată» care este o imposibilitate practică ${ }^{, 23}$. Astfel, postmodernitatea a traumatizat şi alienat conştiinţ̧a omului, fie în raportul său cu Dumnezeu (în care nu mai trebuie să creadă fiindcă „Dumnezeu a murit"), fie în raport cu natura înconjurătoare (pe care să o perceapă ca o simplă materie moartă, fără viață), fie în raport cu ceilalți (reprezentat prin ,a fi pentru Celălalt înainte de a putea fi cu Celălalt" ${ }^{24}$, afirmație care se întoarce tocmai asupra omului şi provoacă anihilarea autonomiei Celuilalt, dominația şi opresiunea).

${ }^{20}$ H. R. Patapievici, op. cit., p. 118.

${ }^{21}$ Ibidem, p. 121.

${ }^{22}$ Sygmunt Baumann, Etica postmodernă, trad. Doina Lică, Timişoara, Edit. Amarcord, p. 15.

${ }^{23}$ Ibidem, p. 14.

${ }^{24}$ Ibidem, p. 18. 
Şi dacă în etica postmodernă, „moralitatea este şi trebuie să fie

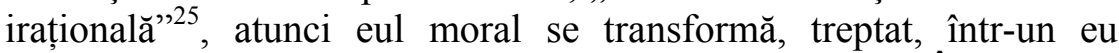
subiectiv, ca în cele din urmă, să ajungă să devină idol. „Însumi idol m-am făcut" zicea Sf Andrei Criteanul sau, aşa cum se exprimă Kirilov din Demonii lui Dostoievsky, „Dacă Dumnezeu nu există, totul este permis”, „Dacă nu există Dumnezeu, atunci eu sunt dumnezeu”. Autoproclamarea omului ca „ființă a lumii” şi pretenția omului, a creaturii, de a deveni dumnezeu dovedeşte clar lipsa dimensiunii spirituale a omului, a orizontului său transcendent, a „ferestrei spre absolut”26. Astfel, ceea ce numim noi, astăzi, criză ecologică este o criză a sistemului de viaţă, a ființei umane însăşi. Este criza omului care „nu mai are rădăcini”, criza de sens a lumii postmoderne care se complace a trăi tot mai mult în afară şi împotriva lui Dumnezeu şi care are ca adversar nihilismul practicat în abordarea noastră cu natura.

În opinia teologului ortodox Emmanuel Clapsis „soluţia unei probleme ecologice nu este, în mod simplu, doar o problemă a managementului şi a tehnicităţii, deşi acestea sunt foarte importante, ci este, în primul rând, o problemă de schimbare a atitudinilor noastre spirituale, o schimbare a viziunii noastre despre lume, de vreme ce există în mod sigur o viziune a lumii care a fost creată şi care susține criza ecologică" 27 , consumismul, care creează omului nevoi false. Sociologul Martin Rock vede redresarea crizei ecologice în eul nostru. „Vom avea un viitor ecologic, spune el, atunci când vom dezinfecta menajul nostru moral (...) Avem nevoie în primul rând de catalizatori ai etosului nostru" 28 .

Ceea ce putem constata e că mentalitatea ecologică în postmodernitate este plină de ciudate contradicții: ecologiştii insistă asupra exigenței sobre a omului în raport cu natura, dar nu văd

\footnotetext{
${ }^{25}$ Ibidem, p. 17.

${ }^{26}$ Viorel Râncu, Criza ecologică şi criza morală, în „Altarul Banatului”, anul XIV (LIII), nr. 4-6, 2003, p. 74.

${ }^{27}$ Clapsis, Emmanuel, Orthodoxy in Conversation, Geneva, WCC Publications, 1994, p. 211.

${ }^{28}$ Viorel Râncu, op. cit., p. 75.
} 
sobrietatea în raport cu alţii, cu semenii, şi mai ales cu ei înşişi. Pe de o parte ecologiștii apără caracterul inalienabil al resurselor naturale, dar, pe de altă parte, ei nu vorbesc nimic despre caracterul sacru al vieții umane şi apără ei înşişi dreptul avortului ${ }^{29}$. Principiul responsabilităţii revendicat atât de mult de ecologişti s-a dovedit a fi „fals”, gol de conținut şi culminând, în cele din urmă, cu realizarea unei culturi individualiste care are drept ideal autonomia individuală: „Sacralizând obligațiile față de ceea ce nu este uman, pasiunile zoofile şi ecofile radicale, s-a alimentat spirala devalorizării postmoraliste a datoriilor interumane. Conştiința verde intransigentă exprimă atât reapariţia noțiunii faţă de responsabilitate faţă de natură cât şi un curent social de deresponsabilizare față de oameni. Oricât de mare ar fi preocuparea ecologică, ea nu e fără legătură cu aprofundarea procesului de desocializare, de autoabsorție şi de indiferență individualistă: sub cetățenia planetară revendicată, se profilează, ici şi colo, un nou antiumanism"30.

Etica ecologică postmodernă s-a dovedit a fi cea care susţine hedonismul ecologic ${ }^{31}$, prelungind într-un alt mod dinamica individualistă centrată pe consum. Consensul ecologic nu a pus câtuşi de puțin capăt cursei creşterii şi consumului individualist, ci a dat naştere unei eco-producții dublate de o ecologie a consumului. Încă o dată, spune G Lipovetsky, „viclenia rațiunii” a învins: nu exigențele absolute ale rațiunii morale verzi au permis restructurarea efectivă a sistemelor productive, ci mai degrabă, dinamica pasiunilor individualiste (securitate, sănătate, bunăstare), a intereselor economice şi a inteligenței tehniciste ${ }^{32}$. Responsabilitatea ecologistă

${ }^{29}$ Franc Rode, Le liberalisme dans la postmodernité, in „Atheisme et foi”, Pontificium Consilium pro dialogo cum non credentibus, vol XXVII, nr. 4, 1992, p. 292.

${ }^{30}$ Gilles Lipovetsky, op. cit., p. 243.

${ }^{31}$ Ibidem, p. 245. Este reprezentativă legătura făcută de Lipovetsky între „ecoconsum şi eco-business". Sensibilitatea ecologică cu exigențele ei referitoare la calitate şi sănătate a permis reorientarea cererii şi ofertei către bioindustrii şi ecoproduse, tehnologii blânde şi curate.

${ }^{32}$ Ibidem. 
s-a dovedit, aşadar, a promova un eco-consumerism individualist, neeliminând dorinţa omului de stăpânire a lumii, fără să mai vorbim de asceză sau de ,idealul de austeritate voluntară" în postmodernitate, care a murit demult.

Conţinutul unei astfel de etici postmoderne a mediului s-a dovedit a fi unul eminamente antropocentrist, pur utilitarist, golit de substanță şi îmbrăcat într-un ambalaj ,,plăcut la vedere”. Sub eticheta respectului față de mediu, poate să se continue concurența economică, dorinţa omului de putere şi înavuţire prin dezvoltarea unei noi direcții eco, a unei eco-industrii, a unei eco-tehnologii etc, toate eco, până la o ,etică de sinteză” care împacă ecologia şi economia, morala şi eficacitatea, calitatea şi creşterea, natura şi profitul $^{33}$. Se constată, încă o dată, triumful rațiunii umane care, din dorinţa de a ieşi din criză, s-a adâncit mai mult în ea.

Încercarea postmodernă de resacralizare a lumii fie prin „simbolul lumii ca dans cosmic”, 34 , fie prin reînviorarea cultului Gaia, propus de mai multe teoloage feministe, prin care pământul trebuie să redevină o ființă vie ${ }^{35}, \mathrm{~s}-\mathrm{a}$ dovedit a fi neputinciosă,

\section{${ }^{33}$ Ibidem, p. 247.}

${ }^{34}$ Jurgen Moltmann, Dumnezeu în creație, O perspectivă ecologică asupra creației, editori: Pr. Emil Jurcan şi Pr. Jan Nicolae, Alba Iulia, Edit. Reîntregirea, 2007, p. 371.

${ }^{35}$ Există multe mişcări de tip New Age care propun ideea de reînsuflețire a naturii. Feminismul sau, mai bine, zis eco-feminismul propune zeificarea pământului prin reînviorarea cultului Gaia, Pământul viu şi sacru. Se arată ideea de fertilitate a materiei, cea care dă viață, materia provenind de la mater, de unde şi aspectul feminin al pământului. Vezi în acest sens Rosemary Radford Ruether, God \& Gaia, An Ecofeminist Theology of Earth Healing, SCM Press LTD, 1993; Teoloaga Rosemary scoate în evidență tendința culturii patriarhaliste care are drept caracteristică dominarea, supunerea (exprimată în situația noastră prin supunerea pământului spre exploatare); pe de altă parte, cultura matriarhală îi oferă protecție pământului. De aici, tendința culturii patriarhale de a identifica femeia cu pământul, materia şi natura, în timp ce bărbatul este identificat cu cerul, intelectul, spiritul transcendent. (p.3); James Lovelock, Gaia, A new look at life on Earth, Oxford University Press, 2000 (în special capitolul Living within Gaia, pp. 115-132) 
impersonală şi străină Revelaţiei, transformându-se într-un panteism camuflat. Tendința zadarnică de reînsuflețire a naturii este surprinsă într-un mod excepțional de H. R. Patapievici atunci când spune că ,postmodernismul exprimă un protest împotriva desacralizarii naturii şi a triumfului unei viziuni ştiintific-pozitiviste asupra lumii. Dar protestul cui? Al unui suflet rănit de asceza omogenizatoare a modernității, dar, în acelaşi timp, şi unul radical lipsit de Dumnezeu. Resacralizarea gnostică (şi uneori satanică) a naturii nu poate deveni religioasă tocmai datorită caracterului esențialmente nihilist al sufletului postmodern. Altfel spus, trauma vine din absența lui Dumnezeu (nihilismul), iar soluția post-traumatică ar vrea ca nihilismul să fie lecuit tot prin nihilism, ceea ce este imposibil şi dovedeşte aporia logică pe care este fondat postmodernismul" "36.

O societate care trăieşte ca şi când Dumnezeu ar fi ,mort”, transformă lumea într-un infern bântuit de tot felul de patimi, iluzii şi idolatrii totalitare. Fără sistemul de valori evanghelice care diferențiază între bine şi rău, între moral şi imoral, se alunecă în ceea ce Sfântul Pavel numeşte ,taina fărădelegii”. Şi de aceea nu e de mirare că ne-am transformat din îngeri protectori ai creației în demoni distrugători, încât un semnal de alarmă înconjură planeta, anunţând ,sfârşitul naturii”, 37 .

\section{Vocația euharistică a creştinului}

Părinții Bisericii au învățat că omul foloseşte lumea ca dar al lui Dumnezeu, hrănindu-se cu mâncarea şi băutura pământului, el descoperă manifestarea vizibilă a raționalității iubirii divine. Sf. Ap. Pavel arată că mâncând hrana trupească, omul îşi hrăneşte, în acelaşi timp, sufletul nu doar cu raționalitatea lumii, ci şi cu dragostea lui Dumnezeu. „Ori de mâncați, ori de beți, ori altceva de faceți, toate spre slava lui Dumnezeu să le faceți” (I Corinteni 10, 31). Astfel, dacă toate lucrurile din lume sunt spre slava lui Dumnezeu, întreaga lume poate fi considerată o manifestare a iubirii sale pentru noi şi

${ }^{36}$ H. R. Patapievici, op. cit., p. 121.

${ }^{37}$ Bil McKibben, The End of Nature, New York, Anchor Books, 1989, p. 111. 
totul intră în relaţie spirituală cu Dăruitorul. ,Întreaga lume ar trebui să fie privită ca parte văzută a unei taine universale, neîntrerupte şi toate activitățile umane drept o comuniune divină, tainică. Concepția lumii ca dar al lui Dumnezeu ori ca mobil al iubirii sale şi ca parte văzută a unei taine a harului lui Dumnezeu, sunt una şi aceeaşi”,38.

În momentul în care omul a descoperit sensurile lumii, nu mai consideră lumea ca ultima realitate, ci se foloseşte de toate câte există în ea cu mulțumire. Un dar îşi arată că îşi îndeplineşte funcția sa de dar, adică funcția de descoperitor al iubirii celui ce-l face, numai când cel căruia îi este adresat îl primeşte cu mulțumire, face din actul primirii un prilej în care îşi manifestă şi el iubirea ${ }^{39}$. Aceasta ne descoperă faptul că cel ce primeşte darul, dăruieşte la rândul său ceva dăruitorului şi astfel, are loc un circuit neîncetat între Dumnezeu şi om prin lume, între iubirea mereu reînnoită şi sporită între $\mathrm{ei}^{40}$. Părintele Stăniloae explică modalitatea în care persoanele umane prin libertate şi muncă pot contribui la transformarea lumii naturale în daruri ale omului oferite lui Dumnezeu. Fiecare persoană are posibilitatea de a alege liber dacă va înmulți sau nu darurile pe care le-a primit. Putem denumi acest fapt un act reciproc de dăruire sau de continuă întoarcere a darului către Dumnezeu. Acest răspuns al omenirii constituie preoția noastră naturală. Ca preot, omul este chemat să recunoască lumea ca dar şi este chemat să o aducă înapoi lui Dumnezeu. Această dăruire preoțească devine mijlocul de comuniune şi înfrăţire cu Dumnezeu. Şi pe măsură ce omul descoperă mai mult frumusețea şi foloasele superioare ale lucrurilor, el aduce tot mai multă mulțumire şi laudă lui Dumnezeu, iar Dumnezeu, pe de altă parte, îi întoarce alte daruri omului cu o mai mare iubire şi binecuvântare.

În acest circuit al darurilor (de la Dumnezeu spre noi şi de la noi spre Dumnezeu) persoana umană nu este în poziţia de a dărui lui Dumnezeu altceva decât ceea ce a primit deja. Astfel, omul înțelege

${ }^{38}$ Dumitru Stăniloae, The world as gift and sacrament of God's love, în „Sobornost”, nr. 2, 1971, p. 667.

${ }^{39}$ Idem, Darul lui Dumnezeu către noi, în „MMS”, XLVI, nr. 3-4, p. 262.

${ }^{40}$ Ibidem, p. 263. 
că percepe lumea ca dar şi ca taină atunci când sacrifică ceva din această lume pentru Dumnezeu, ca semn al iubirii sale recunoscătoare şi ca mobil al acestei iubiri. Iar Dumnezeu, la rândul Său, o întoarce omului în forma darurilor ce conțin o nouă manifestare a iubirii Sale, într-o nouă binecuvântare: „har peste har”. „Fiecare ființă umană este chemată să devină preot al lui Dumnezeu. Deoarece, dacă ființa umană dăruieşte ceva lui Dumnezeu, El îi intoarce darul cu o nouă binecuvântare ca o taină reînnoită. Jertfa ființei umane este întoarsă ca un har reînnoit al lui Dumnezeu; jertfa ființei umane şi harul lui Dumnezeu sunt două aspecte opuse ale acțiunii reciproce a lui Dumnezeu şi a ființei umane. Tot ceea ce se află în posesia omului, cât şi el însuşi devine un sacrificiu, deoarece este oferit lui Dumnezeu de către om şi primit de El. Ulterior, Dumnezeu îl oferă omului care îl primeşte purtând o nouă binecuvântare. La început, a fost un dar sau o taină, dar imediat urmează unirea jertfă-dar. Când omul oferă o jertfă lui Dumnezeu, el dobândeşte o taină, o binecuvântare. Pentru că jertfa umană este oferită lui Dumnezeu în semn de recunoştință pentru tot ceea ce a primit de la El, ea este o Euharistie. Iar omul se împărtăşeşte de această Euharistie, deoarece a devenit pentru el un nou dar oferit de Dumnezeu; primind cu recunoştinţă darul lui Dumnezeu, omul a ajuns la o percepție reală a acestuia. Aşadar, lumea este o taină a iubirii lui Dumnezeu cât şi o Euharistie, o Liturghie a oamenilor încredinţaţi lui Dumnezeu. Pentru om, aspectul de Taină şi de Euharistie sunt inseparabile; fie le înțelegem şi le practicăm pe amândouă, fie nu le înțelegem şi nu le practicăm pe nici una" ${ }^{\text {"11 }}$.

Această slujire preoțească a omului transformă creația într-o împărtăşire de Dumnezeu, prin toate cele create $\hat{I} l$ mâncăm pe Dumnezeu. În acest sens, Sf Ioan Damaschinul interpretează astfel porunca dată de Dumnezeu în rai: „Dumnezeu spune: din tot pomii din rai să mănânci. Prin aceste cuvinte socotesc că a vrut să zică: suie-te, prin toate făpturile, la mine Făcătorule, şi culege din toate un singur fruct, pe Mine, viața cea adevărată. Toate să-ți rodească viața,

${ }^{41}$ Dumitru Stăniloae, The world as gift and sacrament of God's love, p. 668. 
iar împărtăşsirea cu Mine fă-o întărirea existenței tale. În chipul acesta vei fi nemuritor" ${ }^{\prime 2}$. Iar Sf. Ap. Pavel ne spune: „orice aţi face, cu cuvântul sau cu lucrul, toate să le faceți în numele Domnului Iisus, şi prin El să mulţumiți lui Dumnezeu-Tatăl"'(Coloseni 3, 17) sau „mulțumind totdeauna pentru toate”(Efeseni 5, 20). Întreaga creație şi tot ce există în creaţie devine prin om o euharistie, o mulțumire adusă lui Dumnezeu.

Lumea care se interpune între Dumnezeu şi om devine, pentru acesta din urmă, locul în care el actualizează potenţele lumii şi I le aduce lui Dumnezeu ca daruri ale sale. Astfel, în darul creaţiei ca taină, descoperim dragostea lui Dumnezeu pentru noi, iar, în acțiunile noastre menite să actualizeze acest dar al lui Dumnezeu, descoperim dragostea primitorului. Este un circuit al darului de la Dumnezeu spre noi şi de la noi spre Dumnezeu care conține în sine dragostea Dăruitorului şi a primitorului. Este o relație de la Persoană la persoană şi invers. Astfel, lumea nu este doar un dar pentru persoana umană, ci şi o îndatorire, o obligație. Iar această îndatorire, dăruire sau jertfã îl face pe om un sacerdot al lumii, ,un iconom al tainelor lui Dumnezeu"(I Corinteni 4, 1).

\section{Concluzii}

Pentru teologia ortodoxă, ,umanizarea” lumii nu înseamnă că omul dispune de natură, animale şi de toată făptura materială în mod utilitarist, pentru propria satisfacere şi propria plăcere. Lumea umanizată nu înseamnă că lumea devine pentru om proprietatea sa. Dimpotrivă, umanizarea lumii înseamnă a redescoperi sacralitatea acesteia care nu-i este înnăscută (cum pledează holismul teologic al lumii), ci dobândită prin om, care e atât imago Dei, cât şi imago mundi. Omul se dovedeşte a fi astfel nu e un despot, exploatator sau distrugător al creației, ci un ,preot al făpturii zidite”. Or, ca preot al creației înțelegem că lumea a fost încredințată omului nu numai ca să

${ }^{42}$ Sf Ioan Damaschinul, Dogmatica, trad. Dumitru Fecioru, ediţia a III-a, Bucureşti, Edit. Scripta, 1993, pp. 69-70. 
supraviețuiască, ci, mai ales, ,să fie consacrată” prin mâinile omului, ca mijloc de dialog divino-uman.

- În raportul dintre Biserică şi problemele crizei ecologice se vorbeşte mult despre aşa numitul eco-ascetism care vrea să arate că numai printr-o schimbare permanentă a purtării omului (de a dezrădăcina ori de a scoate din noi egoismul ori iubirea de noi înşine care este autonegare voluntară) poate avea un impact pozitiv asupra creației. Criza ecologică se descoperă astfel ca având un caracter moral: degradarea naturii înconjurătoare este rezultatul unui ,păcat colectiv" care nu se deosebeşte cu nimic de păcatul toxicomaniei, al pornografiei ori alcoolismul ${ }^{43}$. Şi tocmai de aceea, înainte de a vindeca natura, trebuie vindecat omul. Salvându-l pe om şi tranformându-1 din ipostas biologic în ipostas eclezial ( cum ar spune Ioannis Zizioulas), este posibil să fie salvată şi lumea, nu însă şi invers. Noi trebuie să ne despătimim, să ne dezbrăcăm pe noi înşine de toate lucrurile care ne stăpânesc, întrucât păcatul ecologic nu constă doar în degradarea pământului prin deforestierea şi vasta industrializare, ci mai ales prin distrugerea energiilor necesare vieții ${ }^{44}$.

- Criza ecologică evidentă, care produce atâta îngrijorare şi nelinişte în zilele noastre, este tocmai produsul crizei spirituale, a tendinței de autonomie, de separare a omului de viața duhovnicească, de Biserică şi de Dumnezeu. Şi aceasta întrucât starea sufletească a omului are un impact nu doar asupra vieții sale, ci şi asupra naturii înconjuratoare. Putem aminti, fără să greşim, că poporul român surprinde atât de expresiv rolul omului în natură atunci când spune că „omul sfințeşte locul”, sau, continuăm noi, omul profanizează locul. Căci sufletul care a rupt legătura cu Dumnezeu ,poluează” atât viața sa personală, cât şi mediul înconjurător. Or, numai forma morală a vieții în Hristos, în duhul eclezial, mai poate trezi conştiinţa omului

${ }^{43}$ Milton B Efthimiou, Orthodoxy and the Ecological Crisis, în "Ecotheology, voices from south and north", Edited by David G Hallmenn, New York, Orbis Books, Maryknoll, 1994, p. 94.

${ }^{44}$ Ibidem. 
postmodern spre conştientizarea că viaţa a fost dată pentru a construi lucruri bune şi nu pentru a o distruge şi a o desființa.

\section{Bibliogafie:}

1.***, Justice, peace and Integrity of Creation, Documents from an Ecumenical Process of Commitment, Edited by D. Preman Niles, Geneva, WCC Publications, 1994.

2.Baumann, Sygmunt, Etica postmodernă, trad Doina Lică, Timişoara, Edit. Amarcord.

3.Clapsis, Emmanuel, Orthodoxy in Conversation, Geneva, WCC Publications, 1994.

4.Culianu, Ioan Petru, Arborele gnozei. Mitologia gnostică de la creştinismul timpuriu la nihilismul modern, Bucureşti, Edit. Nemira, 1998.

5.Idem, Religie şi Putere, Bucureşti, Edit.Nemira, 1996.

6.Efthimiou, Milton, Orthodoxy and the Ecological Crisis, în "Ecotheology, voices from south and north", Edited by David G Hallmenn, New York, Orbis Books, Maryknoll, 1994.

7.Harvey, David, Condiția postmodernității, O cercetare asupra originilor schimbării culturale, trad. Cristina Gyurcsik şi Irina Matei, Timişoara, Edit. Amarcord, 2002.

8.Ică, Ioan jr, Globalizarea-mutații şi provocări, în „Gândirea socială a Bisericii, Fundamente-documente-analize-perspective", Volum realizat şi prezentat de Ioan I. Ică jr şi Germano Marani, Sibiu, Edit. Deisis, 2002.

9.Lipovetsky, Gilles, Amurgul datoriei, Etica dureroasă a noilor timpuri democratice, Trad. Victor-Dinu Vlădulescu, Bucureşti, Edit. Babel, 1996.

10. Lovelock, James, Gaia, A new look at life on Earth, Oxford University Press, 2000.

11. Lyon, David, Postmodernitatea, trad. Luana Schidu, Bucureşti, Edit. DU Style, 1998.

12. McKibben, Bil, The End of Nature, New York, Anchor Books, 1989.

13. Moltmann, Jurgen, Dumnezeu în creație, O perspectivă ecologică asupra creației, editori: Pr. Emil Jurcan şi Pr. Jan Nicolae, Alba Iulia, Edit. Reîntregirea, 2007.

14. Patapievici, Horia, Omul recent, $O$ critică a modernitățiidin perspectiva întrebării "Ce se pierde atunci când ceva se câş̧tigă?", Bucureşti, Edit. Humanitas, 2005. 
15. Râncu, Viorel, Criza ecologică şi criza morală, în „Altarul Banatului", anul XIV (LIII), nr. 4-6, 2003.

16. Rode, Franc, Le liberalisme dans la postmodernité, in „Atheisme et foi", Pontificium Consilium pro dialogo cum non credentibus, vol XXVII, nr. 4, 1992.

17. Sf Ioan Damaschinul, Dogmatica, trad. Dumitru Fecioru, ediţia a III-a, Bucureşti, Edit. Scripta, 1993.

18. Stăniloae, Dumitru, Darul lui Dumnezeu către noi, în „MMS”, XLVI, nr. 3-4.

19. Idem, The world as gift and sacrament of God's love, în „Sobornost”, nr. 2, 1971. 